\title{
A review of the consideration of climate change in the planning of hydropower schemes in sub-Saharan Africa
}

\section{M Lumbroso', G Woolhouse ${ }^{1}$ and L Jones ${ }^{2}$}

${ }^{1}$ HR Wallingford Ltd, Howbery Park, Wallingford, Oxfordshire OX10 8BA, UK

2 Overseas Development Institute, 203 Blackfriars Road, London SE1 8NJ, UK

Published in Climatic Change, December 2015, Volume 133, Issue 4, pp 621-633

The original publication is available at www.springerlink.com

\section{Abstract}

There are over 580 million people in sub-Saharan Africa without access to electricity. The region has significant untapped hydropower potential that could contribute to improving domestic access to electricity and countries' economic development, as well as helping to meet the Sustainable Development Goals. Changes in climate affect hydropower generation through alterations to river flow regimes. Hence it is the energy source most likely to be affected by climate change because the amount of electricity generated is directly related to water quantity and its timing. However, climate change impacts are rarely explicitly considered when planning new hydropower projects in the region. This may be because current fluvial discharge series in sub-Saharan Africa display high levels of natural variability and it is only after the 2050s that climate-driven changes in river flows emerge from these. Planning horizons of hydropower projects are usually around 30 years, so the natural variability of the existing hydrological regime is within the variability of climate change projections and hence it is unlikely to be considered. Another reason is that over the past 15 years China has become a significant financer of infrastructure in the region. China only meets the environmental regulations of the country in which the hydropower scheme is being constructed. Most subSaharan African countries do not have regulations that include climate change in the planning of such projects. This paper concludes by suggesting a framework via which climate change can be incorporated in future hydropower schemes at a river basin scale.

Key words: climate change; hydropower; sub-Saharan Africa

\section{Introduction}

Modern electricity services are important for human well-being and to a country's economic development; however; worldwide there are over 1.3 billion people without access to power (IEA, 2011). Sub-Saharan Africa lags behind all other regions of the world in terms of households' access to electricity (Golumbeanu \& Barnes, 2013). Table 1 and Figure 1 provide examples of access to electricity and electricity consumption in some of the larger sub-Saharan African countries. 
Table 1 Examples of the access to electricity in some sub-Saharan Africa countries

\begin{tabular}{|l|c|c|}
\hline \multicolumn{1}{|c|}{ Country } & $\begin{array}{c}\text { Population without } \\
\text { access to } \\
\text { electricity (million) }\end{array}$ & $\begin{array}{c}\text { Percentage of } \\
\text { population without } \\
\text { access to electricity }\end{array}$ \\
\hline Nigeria & 76 & $49 \%$ \\
\hline Ethiopia & 69 & $83 \%$ \\
\hline Democratic Republic of the Congo & 59 & $89 \%$ \\
\hline Tanzania & 38 & $86 \%$ \\
\hline Kenya & 33 & $84 \%$ \\
\hline Other sub-Saharan Africa countries & 310 & $68 \%$ \\
\hline Total & $\mathbf{5 8 5}$ & $\mathbf{6 9 \%}$ \\
\hline
\end{tabular}

(Source: IEA, 2011)

There is some debate as to what constitutes a minimum "reasonable" level of electricity consumption. The International Energy Agency (IEA) states that $100 \mathrm{kWh} /$ year/person ${ }^{1}$ is an initial "reasonable" level of consumption (IEA, 2011). However, this level of use is only equivalent to powering a single 60 watt light bulb for 4.5 hours per day, which is not a defensible modern level of energy access (Moss and Gleave, 2014).

"Middle income" African countries such as Tunisia (1,300 kWh/year/person) or South Africa $(4,600 \mathrm{kWh} /$ year/person) offer potential target levels that are closer to a modern standard of living (Moss and Gleave, 2014).

There is currently around $98 \mathrm{GW}$ of installed generating capacity in sub-Saharan Africa. To raise subSaharan Africa's access to electricity to the level available in South Africa by 2030 would require 1,000 GW of installed capacity (Bazilian and Pielke, 2014). Sub-Saharan Africa has significant untapped hydropower potential that could contribute to improving domestic access to electricity and countries' economic development.

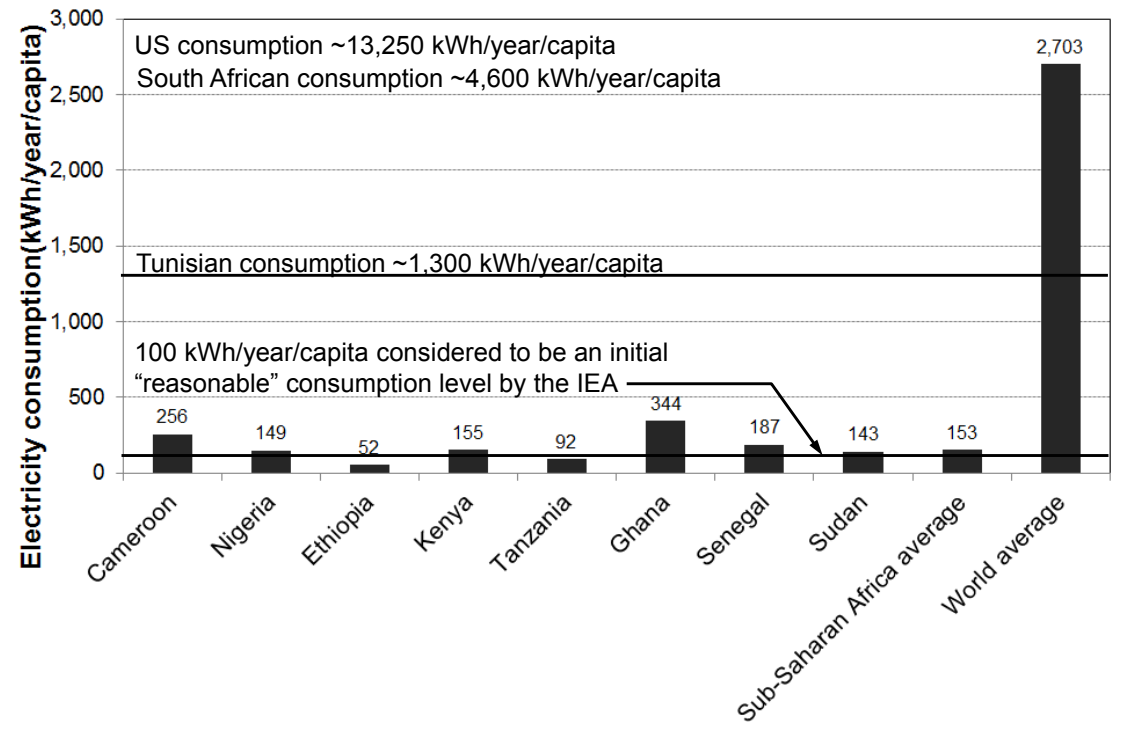

Figure 1 Examples of current electricity consumption in sub-Saharan Africa

1 An average American would consume $100 \mathrm{kWh}$ in about three days (Moss and Gleave, 2014) 
Hydroelectricity is generated by water falling under the force of gravity that turns the blades of a turbine, which is connected to a generator. The capacity to generate electricity is dependent on both the flow of available water and height from which it falls. Observed warming over a number of decades points to considerable changes in the large-scale hydrological cycle, including: increased atmospheric water vapour content; changing precipitation patterns, intensity and extremes; reduced snow cover and widespread melting of ice; and changes in soil moisture and runoff (Bates et al 2008). The impacts of future climate change are projected to have strong implications on freshwater resources and, as a result, likely to affect hydropower generation through changes in the mean annual stream flow, shifts of seasonal flows and increases of stream flow variability (including floods and droughts), as well as by increased evaporation from reservoirs and changes in sediment fluxes (IPCC, 2014). This means that it is the energy source most likely to be affected by climate change because the amount of electricity generated is directly related to water quantity and its timing (IPCC, 2014). This paper reviews the consideration of climate change in the planning of hydropower schemes in sub-Saharan Africa and makes recommendations as to how it can be taken into account in the future.

\section{Background to hydropower in sub-Saharan Africa}

The World Bank has asserted that promoting the development of hydropower will lower the generation costs of electricity, reduce carbon emissions and help to insulate countries in sub-Saharan Africa from increases in the price of fossil fuels (World Bank, 2009). In the next 20 to 30 years, based on planned schemes, the hydropower generating capacity in Africa could almost quadruple to almost $100 \mathrm{GW}$ (Hamududu \& Killingtveit, 2012). Figure 2 shows the potential for the development of hydropower in Africa compared to other continents. Many countries in sub-Saharan Africa's are already highly dependent on hydropower, and an increase in this dependency will augment the risks from droughts (e.g. a reduction in power generation) (see Cole et al., 2013). There is already evidence of drought-induced power cuts in many "hydro-dependent" sub-Saharan Africa countries leading to reductions in Gross Domestic Product (see Lumbroso et al., 2014).

In Africa, regional power generation and interconnection projects play a significant role in the strategies for increased access to electricity. The Regional Economic Communities (RECs) promote regional power projects and trade through their respective power pools shown in Figure 3. The percentage of installed capacity in terms of the four main types of power generation (i.e. hydropower, diesel, coal and gas) is shown in Figure 3. In sub-Saharan Africa, hydropower makes up just under $20 \%$ of the installed generating capacity i.e. around $19.7 \mathrm{GW}$. However, when South Africa is excluded, from the overall figures, hydropower accounts for about $50 \%$ of installed capacity (Eberhard et al., 2008). By 2025, the power generation mix within these power pools will be moving substantially toward an increasing share of hydropower (ICA, 2011). In 2009 it was estimated that in sub-Saharan Africa there were hydropower schemes with over $7.9 \mathrm{GW}$ of capacity currently under construction and further hydropower schemes with an installed capacity of between approximately 25 to $98 \mathrm{GW}$ being planned (Hydropower and dams, 2009). 


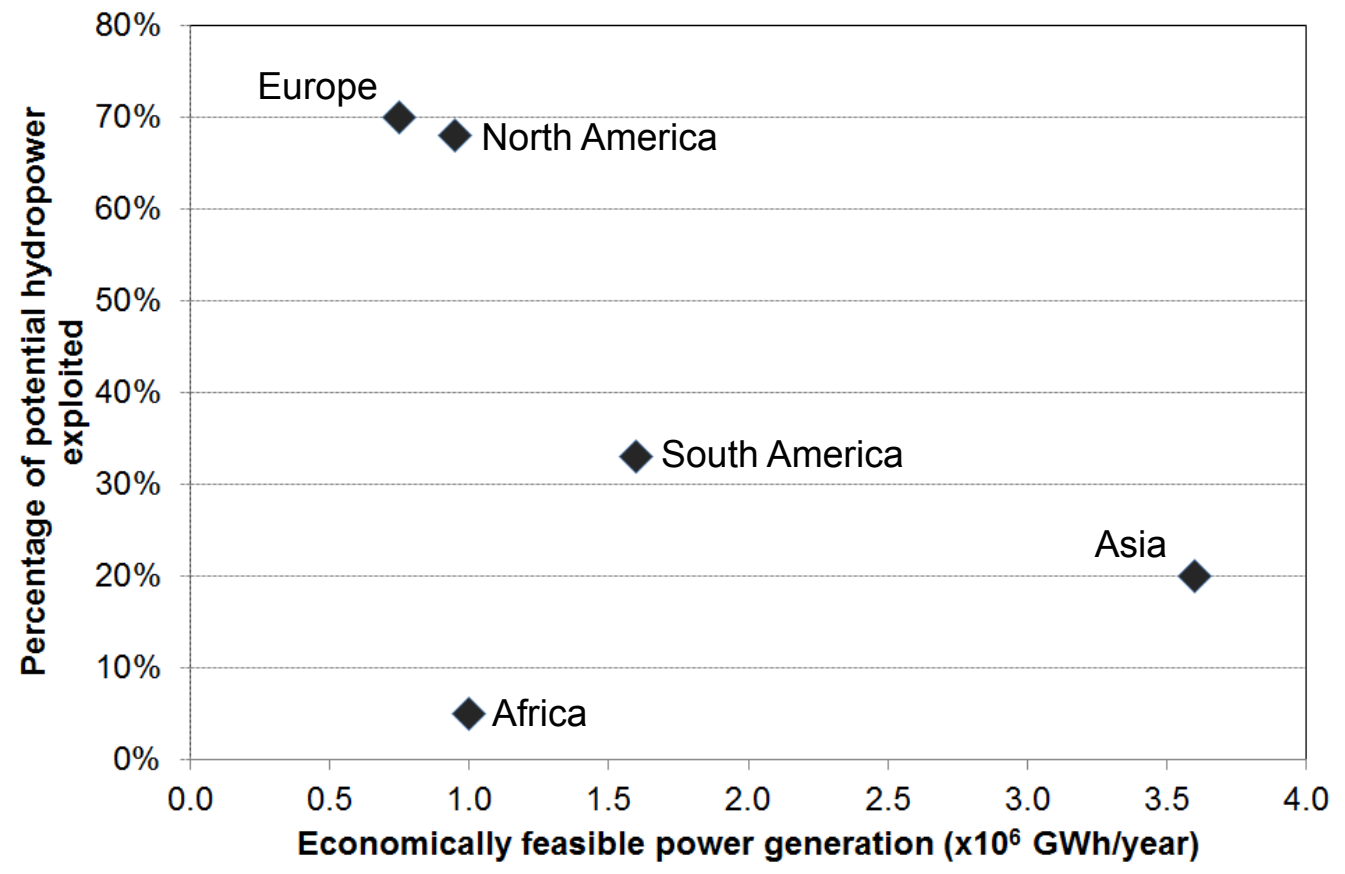

Figure 2 Potential and actual hydropower generation in different regions Source: Based on data available from the World Bank, 2014

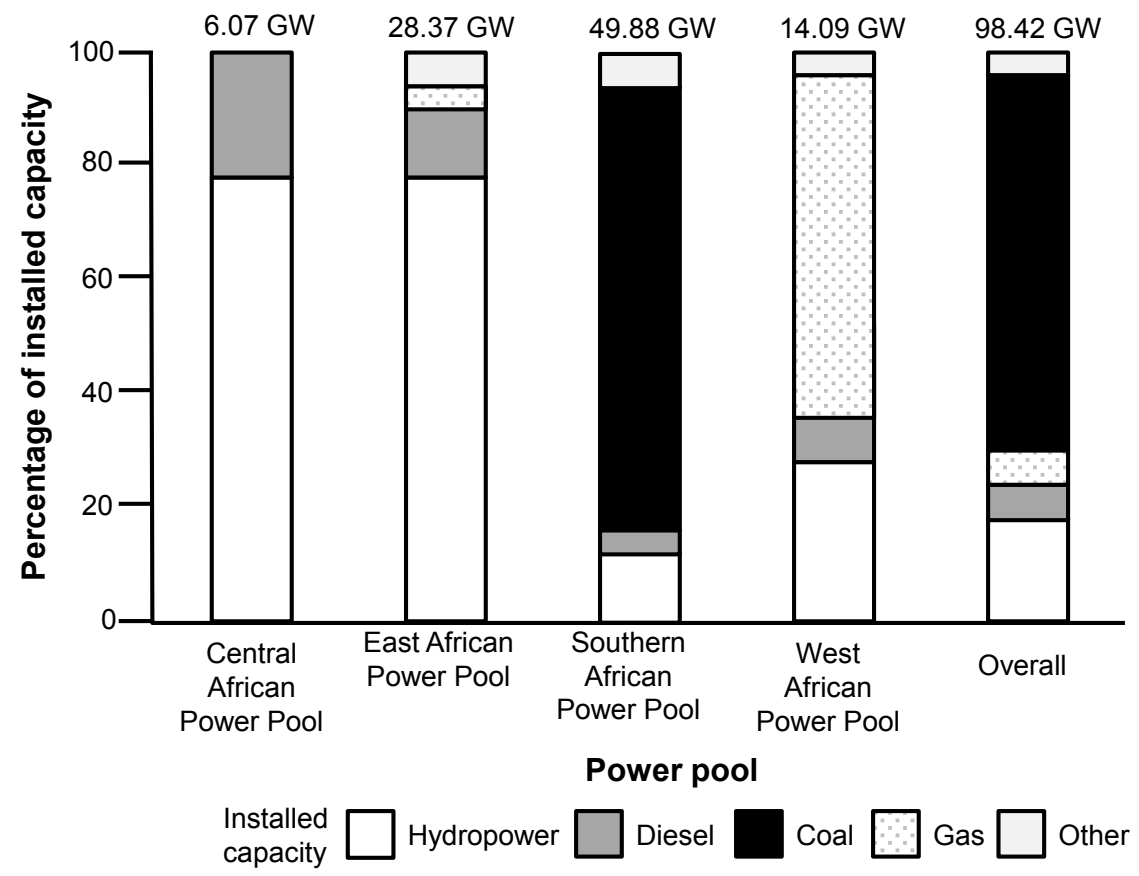

Figure 3 Generation technology as a percentage of the installed capacity in the four sub-Saharan African power pools

Note: When South Africa is excluded, from the overall figures hydropower accounts for close to $70 \%$ of electricity production (or about $50 \%$ of installed generation capacity) (Eberhard et al., 2008) 


\section{The impacts of climate change on hydropower}

The potential impact of climate change on water resources has been postulated since the 1980s (Němec \& Schaake, 1982). However, the impacts of climate change through temperature and rainfall pattern changes upon hydrological cycles are complex and poorly understood in most low income countries (Harrison and Whittington, 2001). Although Global Climate Models (GCMs) can be used to predict runoff directly, their coarse scale means that this information is only useful for the most general of studies (Kumar et al., 2011). As a result, studies that have been carried out on individual river basins show that basins display a range of sensitivities to climate change.

Climate change is a particular threat to many existing and planned hydropower schemes because many of these schemes could still be in operation in 50 or even 100 years time, when the effects of climate change may in some cases be substantial (Giordano, 2012; Schaeffer et al., 2012). Long-lived infrastructure ${ }^{2}$, such as hydropower schemes, is generally less adaptable to climate change because such infrastructure is challenging to alter retrospectively (Pittock, 2010). The ability to influence adaptation strategies and measures for the various stages of a hydropower scheme is shown in Figure 4.

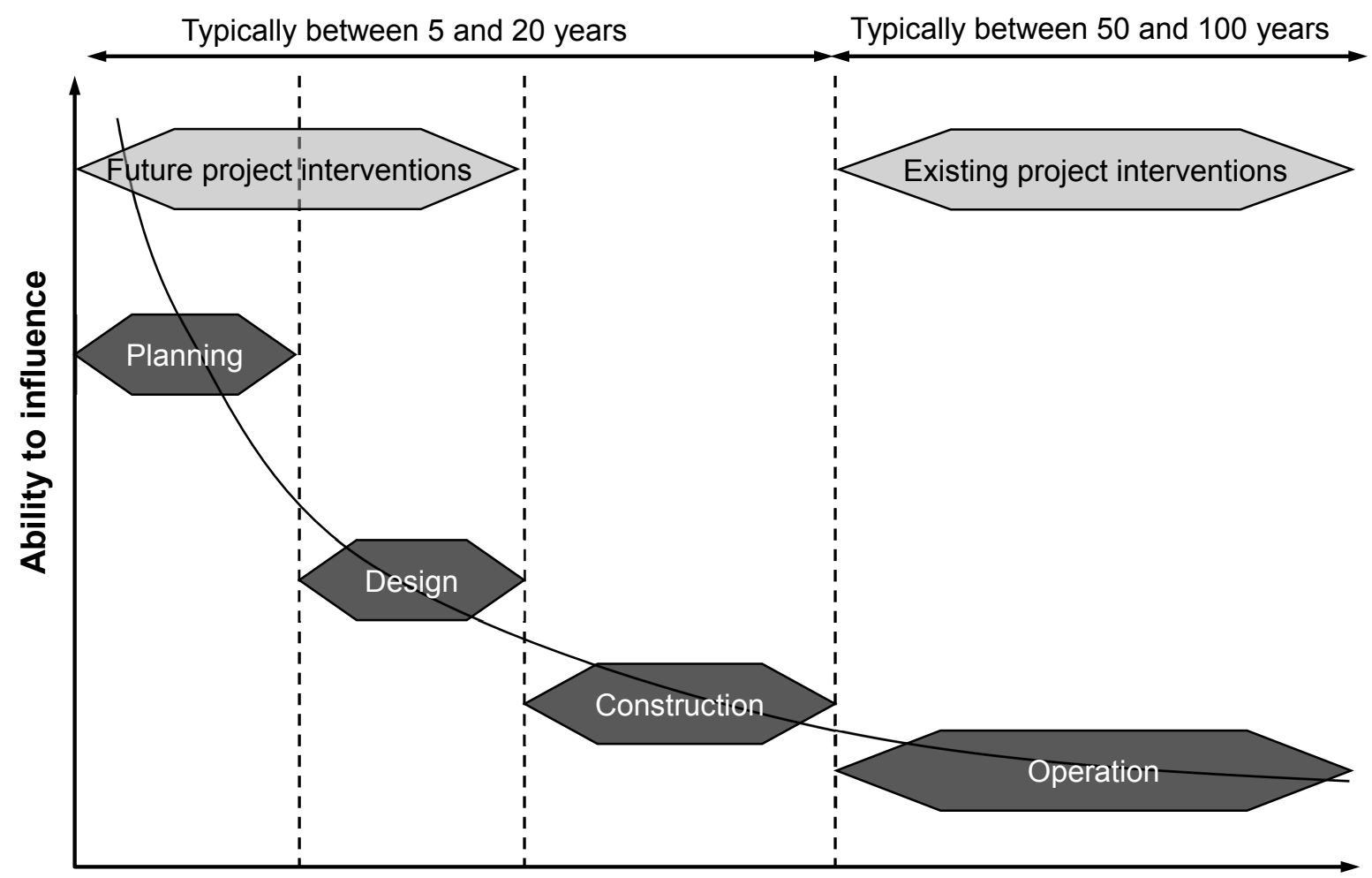

Time

Figure 4 The ability to influence climate change adaptation measures for hydropower schemes Source: Adapted from MWH, 2009

Future hydropower performance and dam safety is likely to be affected by climate change in the following ways:

2 These are pieces of infrastructure that usually can be maintained for a significantly greater number of years (i.e. 50 to 100 years) than most other capital assets 
- Changing quantities, as well as spatial and temporal patterns, of rainfall and river flows could increase or decrease the period when turbines can operate at full capacity;

- Increased evaporation rates from reservoir surfaces, as a result of changes in air temperature and humidity could reduce the water available for power generation;

- Increases in sediment loads in rivers, as a result of more intense rainfall would increase rates of reservoir sedimentation leading to loss of storage and damage to turbine blades;

- Increased flood magnitudes could lead to an increased probability of dam failures, as a result of spillways not being able to pass the flood flow safely increasing the risk to people downstream.

\section{The incorporation of climate change in the planning of hydropower schemes in sub-Saharan Africa}

Despite the apparent need, Pottinger (2009) and limi (2007) argue that climate change impacts are rarely explicitly considered when planning hydropower projects (Pottinger, 2009; limi, 2007). This is particularly the case in the context of sub-Saharan Africa. A recent scoping study conducted for the World Bank noted that: "Most hydropower/reservoir operators do not see climate change as a particularly serious threat. The existing hydrological variability is more of a concern, and the financially relevant planning horizons are short enough that with variability being much larger than predicted changes, the latter do not seem decisive for planning" (Rydgren et al. 2007).

The implementation of a number of large hydropower schemes in sub-Saharan Africa provide further weight to the views of Pottinger, limi and Rydgren et al. In April 2011, the Ethiopian Government commenced construction of the Grand Ethiopian Renaissance Dam , a hydropower dam on the Blue Nile, which will generate approximately 6,000 MW of electricity and will cost nearly US $\$ 5$ billion (Hammond, 2013). In 2013 an international panel of experts assessed various aspects of the project. The panel noted that the scheme's sensitivity to and the potential impacts that could result from climate change had not been taken into account in the planning and design of the dam. The expert panel stated that: "A project of this scale and with such heavy reliance on rainfall patterns requires a better understanding of future hydrologic conditions to ensure the highest degree of flexibility and resiliency in its design and operation. The panel recommends a study that looks at the potential influence of climate change on the flow regime at the Grand Renaissance Dam and further downstream" (International Panel of Experts Grand Renaissance Dam, 2013). In addition climate change is likely to affect sedimentation rates and no analysis of this is thought to have been undertaken (Chen \& Swain, 2014).

Ghana has been experiencing a severe energy shortage as a result of the low water levels and capacity problems at the existing Akosombo Dam on the River Volta, which supplies around $60 \%$ of Ghana's electricity (Sackitey, 2012). To increase Ghana's generating capacity the construction of the Bui Dam hydropower scheme was commenced. In 2007, the Chinese government agreed to a loan of US $\$ 622$ million to cover the construction costs of the dam and its $400 \mathrm{MW}$ power station. The scheme was completed in 2014 (Government of Ghana, 2014). The planning for the project disregarded the potential for climate change to reduce the dam's power output (International Rivers, 2014).

The Zambezi River, which drains the largest catchment in southern Africa, an area of around 1.4 million $\mathrm{km}^{2}$, (Beilfuss \& dos Santos, 2001), is still relatively undeveloped in terms of hydropower schemes (SpaldingFecher, et al., 2014). There is currently about $5,000 \mathrm{MW}$ of installed hydropower generation capacity in the basin, including the $130 \mathrm{~m}$ high Kariba Dam, (1,600 MW of installed capacity), the $170 \mathrm{~m}$ high Cahora Bassa dam (2,075 MW of installed capacity) and Kafue Gorge hydropower scheme (990 MW of installed capacity) (Beilfus, 2012). The Zambezi River basin has been assessed to have an additional 11,000 to $13,000 \mathrm{MW}$ of hydropower potential of which around 6,600 MW is to be implemented before 2025 (SpaldingFecher, et al., 2014). 
None of the current or proposed hydropower schemes in the Zambezi River basin have taken into account climate change effects into their project planning, design or operation in a meaningful way (Beilfuss, 2012; Kling et al., 2014). In addition, plans for new hydropower schemes in the basin do not appear to take cognisance of how the upstream demands for water, particularly crop water requirements, may increase owing to an expansion in irrigable areas and climate change (Spalding-Fecher, et al., 2014).

There may also be complacency in certain parts of the continent because the results of several GCMs for certain regions of sub-Saharan Africa predict an increase in annual average precipitation under various scenarios. However, these figures mask the temporal variability of the data that indicates that droughts will have a greater probability of occurrence in these areas (ECA, 2009). This temporal variability is important. For example, for the proposed Batoka Gorge scheme on the Zambezi it was found that future decreases in rainfall will have a greater impact than increases. Under a wet climate change scenario, (an increase in precipitation of $20 \%$ ), power production was found to be raised by $7 \%$ and $18 \%$ for high and low flow periods, respectively, while under the dry scenario, (a decrease in rainfall of $20 \%$ ), monthly power output decreased by $23 \%$ and $30 \%$ on the same basis (Harrison et al., 2003).

\section{Discussion}

Few studies have assessed the effects of climate change on hydropower resource potential in Africa (Kumar et al., 2011). There are even fewer studies for the planning and design of new schemes that have taken into account the impacts of climate change on hydropower generation. This raises the question as to why this is the case?

One of the reasons is that river flows in sub-Saharan Africa display high levels of variability across a range of spatial and temporal scales (Conway et al., 2008; Kling et al., 2014). Future changes in trends in river flows and rainfall related to climate change will need to be large and prolonged over time, in order to enable formal attribution, and to create conditions beyond those which have already been experienced during the $19^{\text {th }}$ and $20^{\text {th }}$ centuries (Conway et al., 2008).

This variability has important consequences for the management of hydropower schemes under future climate change scenarios. The lifetime of hydropower infrastructure is around 100 years, meaning that new schemes implemented in in the next decade are still likely to be operating into the next century. The financial planning horizons for cost recovery for hydropower schemes currently being planned rarely stretch beyond 2050 (IRENA, 2013). In sub-Saharan Africa, it is only after the 2050s that climate-driven changes in rainfall and river flows are expected to emerge from natural variability (Footitt et al., 2007). Hence, if the financial planning horizons of water resources projects are 25 to 30 years, this means that when planning a hydropower scheme, the natural variability of the existing hydrological regime is often within the variability of climate change projections. Hence many of the effects of climate change fall beyond typical financial planning time scales and thus are less likely to be taken into account.

Sub-Saharan African countries face the challenge of responding to the immediacy of core development needs and the many challenges regarding the delivery of and access to basic public services remain (Mullan et al., 2011). As a consequence there is a tendency for many African governments and policy-makers to focus on short-term policy interventions. In sub-Saharan Africa, apart from in South Africa, climate change is not systematically integrated into longer-term planning and investment decision-making (IRI, 2006). In much of sub-Saharan Africa there would also appear to be a lack of effective institutional arrangements to facilitate the generation, analysis and systematic integration of relevant medium and long-term climate information to guide infrastructural investments and planning decisions (IRI, 2006).

It is also important to note that a calculation of the internal rate of return is often used by international funding agencies such as the World Bank to assess the viability of investments in long-lived infrastructure. When calculating the internal rate of return of a project, the mathematical function used is such that a small value is put on income and/or costs incurred beyond 25 to 30 years into the future. As discussed above, within this planning horizon increases in the hydrological variability of river basins in sub-Saharan Africa as a result of climate change will not be distinguishable from the historical variability. This is possibly why "hydropower operators do not see climate change as a particularly serious threat" (Rydgren et al., 2007). 
Another factor is that, in recent years, the China Export-Import (Exim) Bank has become a significant new financer of power infrastructure in sub-Saharan Africa (Bräutigam, 2010). The 1,250 MW Merowe Dam, in Sudan, only went ahead because the China Exim Bank agreed to finance it (International Rivers, 2012). Over the period 2001 to 2006, Chinese financing commitments to the sub-Saharan African power sector averaged US $\$ 1.7$ billion per year, which is equivalent to around $0.2 \%$ of the region's Gross Domestic Product and more than official aid and other private investment combined (Eberhard et al., 2008). There are some 70 major hydropower projects with Chinese involvement in Africa (Pöyry, 2011). The main focus of Chinese support has been the development of six large hydropower projects with a combined generating capacity of over 7,000 MW, which once completed should increase the region's installed hydropower capacity by $40 \%$ (Eberhard et al., 2008).

When implementing hydropower schemes in sub-Saharan Africa China only subscribes to the environmental framework of host countries (Bräutigam, 2010; Bond et al., 2012), which generally do not have regulations to include climate change in the planning of hydropower schemes. It would appear that water projects in China do not fully consider the possible effects of climate change, that Chinese policy on climate change is fragmented and that hydropower schemes in China often lack a proper environmental impact assessments (He, 2013; Marks, 2010; Cameron \& Wei, 2013). This is probably why Chinese financed hydropower schemes in sub-Saharan Africa do not take account of climate change in their planning and design. The other reason is that there are few financial incentives for China to invest heavily in the uptake of climate information into the design and implementation of African infrastructure, as any costs will likely be borne outside of the investment windows.

There are also governance issues in trans-boundary river basins in sub-Saharan Africa. These can mean that climate change is not taken into account when planning large infrastructure projects. For example, tensions between managing water within natural boundaries and managing water within national borders have been increasing (McCornick et al., 2013). Competing political and economic interests between countries in trans-boundary river basins are challenging to resolve (McCornick et al., 2013). The Blue Nile River basin is an important resource shared by Ethiopia, Sudan and Egypt. There is significant uncertainty about the likely impacts of climate change in the basin, and currently no comprehensive integrated water resources management or adequate monitoring infrastructure exists (Veilleux, 2013). Some GCMs indicate that there will be more rainfall and some less. Future climate change will affect river flows increasing uncertainty over future water availability for hydropower. These implications are often ignored by planners in the region and new hydropower schemes are not planned within the context of the whole river basin.

Although public agencies around the world have put in place broad requirements that water resource infrastructure should incorporate climate change, there is a dearth of guidelines specifying how this should be done. Designers of hydropower plants are left with the challenge of being asked by funding agencies to incorporate climate change scenarios into their plans and operations of these schemes, but without any appropriate guidance as to how this should be done or the necessary skills. In some sub-Saharan African countries the use of climate change scenarios in planning water resources infrastructure involves a level of complexity that goes beyond the capacity of national and local water institutions (FitzGibbon \& Mensah, 2012). It is also important to note that the supply of adequate climate information both in terms of quantity and quality with which to plan hydropower schemes in sub-Saharan Africa remains a major challenge. This is in large part due to poorly developed and/or the deteriorating state of climate services across much of subSaharan Africa (Adeaga, 2007; Dinku, et al., 2014).

\section{Conclusions}

The evidence available suggests that although the best available historical hydro-meteorological data are generally used in the planning and design of hydropower schemes, the impact of climate change is rarely taken into account. Several studies to assess the effects of climate change on hydropower performance in sub-Saharan Africa have been carried out (see Grijsen, 2014; Harrison et al., 2003; Kim et al., 2008; Jeuland \& Whittington, 2013). However, they have either been carried out after the hydropower scheme has been constructed or as academic exercises. 
Climate change accentuates the risks related to the development of new hydropower schemes because stationarity ${ }^{3}$ in future river flow series can no longer be assumed (Milly et al., 2008). Future climate change scenarios should thus be incorporated into the planning of hydropower schemes, as a matter of course, to help to avoid over- or under-designed infrastructure and financial risk, and to improve its climate resilience. Through this improved understanding of the sensitivity of potential hydropower schemes to climate variability and change, future emphasis should focus on investing in schemes that place a premium on maximising robustness so that the infrastructure performs well under a wide range of future scenarios (see Groves \& Lempert, 2006; 2010).

When assessing new hydropower schemes it is important that studies are carried out, with the commensurate level of detail, that allows the trade-offs between hydropower generation, food security, water supply and other users of water to be assessed under a range of climate change scenarios, ideally at a catchment scale. These new approaches are needed because uncertainties related to future climate change and water demands have been shown to have a significant effect on the benefits (e.g. amount of power generated, economic return) of large hydropower dams (Harrison \& Whittington, 2001; Jeuland \& Whittington, 2013). The costs of carrying out these studies is small compared to the capital costs of these schemes.

With the data currently available it is difficult to distinguish between hydropower schemes that have: (i) disregarded climate change; (ii) considered it but taken no action and (iii) those that have taken cognisance of it in their design, financing and operation. This conclusion was also reached by Cole et al., 2013. Future hydropower schemes in sub-Saharan Africa should be planned within a framework of Integrated Water Resource Management ${ }^{4}$. Figure 5 shows a diagrammatic representation of the process that could be used at a basin scale to assess the performance of new hydropower schemes under different future climate change scenarios within the water-energy-food nexus. This process accounts for not only the impacts of climate change, but also the trade-offs between agricultural productivity, domestic and industrial water demands, and changes in resource availability in order to allow different future scenarios to be assessed.

3 Natural systems that fluctuate within an unchanging envelope of variability

4 Integrated Water Resources Management (IWRM) is a process which promotes the coordinated development and management of water, land and related resources in order to maximise economic and social welfare in an equitable manner without compromising the sustainability of vital ecosystems (GWP, 2014) 


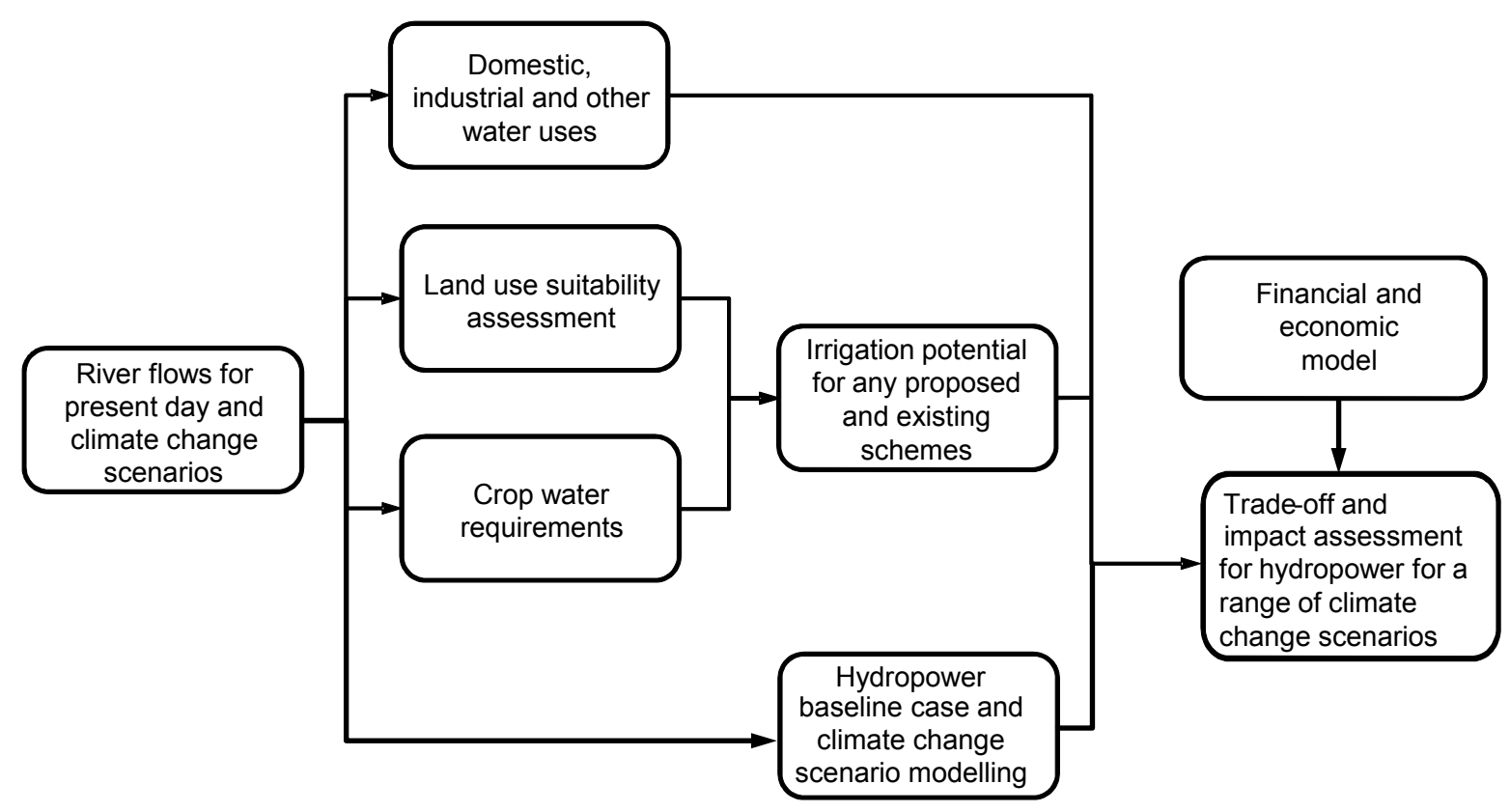

Figure 5 Diagrammatic representation of the process that should be adopted to incorporate climate change and to look at trade-offs between hydropower, agriculture and water security at a basin scale

Such an approach encourages robustness in the planning, design and operation of new hydropower schemes and helps to avoid maladaptation to climate change. The process requires a simulation of the links between climate change, the basin's hydrology and future demands of the environmental, agriculture, industrial and domestic users to examine the sensitivity of the performance of the new scheme to various climate change scenarios, as well as other uncertainties. The results, in some cases, may show that there is no single scheme that performs best across a range of future climate conditions and other, as is the case in the work carried out by Jeuland \& Whittington, 2013. However, the value of this approach is that it can be used to identify a range of 'low-regrets' hydropower scheme options that will provide benefits under future climate change scenarios.

\section{References}

Adeaga, O. (2007) Constraints and prospects of hydrological science practices in sub-Saharan Africa, in International Association of Hydrological Sciences, HW3009 4841 - 4847, Workshop on loss of knowledge

African Development Bank (AfDB) (2013) The high cost of electricity generation in Africa [WWW] http://www.afdb.org/en/blogs/afdb-championing-inclusive-growth-across-africa/post/the-high-cost-ofelectricity-generation-in-africa-11496/ (Accessed 23 December 2014)

Bates, B.C., Z.W. Kundzewicz, S. Wu and J.P. Palutikof, Eds., 2008: Climate change and water. Technical paper of the Intergovernmental Panel on Climate Change, (IPCC) Secretariat, Geneva, 210 pp.

Bazilian, M., Nussbaumer a, P., Rogner, H-H, Brew-Hammond, A., Foster, V., Pachauri, S., Williams, E., Howells, M., Niyongabo, P., Musaba, L., Ó Gallachóir, B., Radka, M and Daniel Kammen, M. (2012) Energy access scenarios to 2030 for the power sector in sub-Saharan Africa, Utilities Policy, 20, pp1-16

Bazilian, M. and Pielke, R. (2013), Making energy access meaningful, Issues in science and technology 
Beilfuss, R. (2012) A risky climate for southern African Hydro: Assessing hydrological risks and consequences for Zambezi River basin dams. International Rivers. Available at: http://www.internationalrivers.org/files/attached-files/zambezi climate report final.pdf (Accessed 23 December 2014)

Beilfuss, R. and dos Santos, D. (2001) Patterns of hydrological change in the Zambezi Delta. Technical report Working Paper 2. Program for the Sustainable Management of Cahora Bassa Dam and the Lower Zambezi Valley, International Crane Foundation, Wisconsin, USA

Bond, P., Allen, F., Amisi, B., Brunner, K., Castel-Branco, R., Dorsey, M., Ernsting, A., Gambirazzio, G., Hathway, T., Nel, A, Nham, W., and Sharife, K. (2012) From The CDM in Africa cannot deliver the money and why the carbon trading gamble and Clean Development Mechanism won't save the planet from climate change and how African civil society is resisting!

Bräutigam, D. (2010) China, Africa and the international aid architecture, Working Papers Series No. 107, African Development Bank, Tunis, Tunisia

Cameron, A. and Wei, L (2013) An environmental impact assessment for hydropower development in China, Vermont Journal of Environmental Law Available at [WWW] http://www.lead-journal.org/content/13050.pdf (Accessed 12 January 2015)

Chen, H. and Swain, A. (2014) The Grand Ethiopian Renaissance Dam: Evaluating its sustainability standard and geopolitical significance, Energy Development Frontier, March 2014, Volume 3 Issue 1, pp1119

Cole, M.A., Elliott, R.J.R and Strobl, E. (2013) Climate change, hydro-dependency and the African dam boom, University of Birmingham, Department of Economics Discussion Paper 14-03

Conway, D. Persechino, A., Ardoin-Bardin, S., Hamandawana, H., Dieulin, C. and Mahe, G. (2008) Rainfall and water resources variability in sub-Saharan Africa during the 20th century, Journal of Hydrometeorology

Davies, M. Edinger, H., Tay, N. and Naidu, S. (2008) How China delivers development assistance to Africa, Centre for Chinese Studies, University of Stellenbosch, South Africa

Dinku, T., Block, P., Sharoff, J., Hailemariam, K., Osgood, D., del Corral, J., Cousin, R. and Thomson, M. (2014) Bridging critical gaps in climate services and applications in Africa. Earth Perspectives 2014 pp1-15

Eberhard, A., Foster, V., Briceño-Garmendia, C., Ouedraogo, F., Camos, D. and Shkaratan, M. (2008) Africa infrastructure: country diagnostic: Underpowered: The state of the power sector in sub-Saharan Africa, World Bank, Washington DC Available at:[WWW] http://www.eu-africa-infrastructure-

tf.net/attachments/library/aicd-background-paper-6-power-sect-summary-en.pdf [Accessed 1 October 2014]

Economics of Climate Adaptation (ECA) (2009) Shaping climate-resilient development: A report of the economics of climate adaptation working group, A report of the economics of climate adaptation working group: A framework for decision-making

FitzGibbon, J. and Mensah, K. (2012) Climate change as a wicked problem: An evaluation of the institutional context for rural water management in Ghana, SAGE Open, April-June 2012, pp1-14

Footitt, A., Hedger, M.M., Kristensen, P., Leipprand, A., Dworak, T., Wilby, R., Huntington, J., van Minnen, J. and Swart, R. (2007) Climate change and water adaptation issues. European Environment Agency (EEA) Technical report No 2/2007. ISSN 1725-2237, ISBN 978-92-9167-917-1. Copenhagen: EEA 
Giordano, T. (2012) Adaptive planning for climate resilient long-lived infrastructures, Utilities Policy, Volume 23, December 2012, pp80-89

Global Water Partnership (GWP) (2014) Global Water Partnership - What is IWRM? Available at [WWW] http://www.gwp.org/The-Challenge/What-is-IWRM/ (Accessed 5 December 2014)

Golumbeanu, R. and Barnes, D. (2013) Connection charges and electricity access in sub-Saharan Africa, Policy research working paper 6511, World Bank, Washington DC

Government of Ghana (2014) Bui and the tale of three hydro dams [WWW] http://www.ghana.gov.gh/index.php/2012-02-08-08-32-47/features/4537-bui-and-the-tale-of-three-hydrodams (Accessed 26 December 2014)

Grijsen, J. (2014) Understanding the impact of climate change on hydropower: The case of Cameroon -. Climate risk assessment for hydropower generation in Cameroon,. Africa Energy Practice, Washington DC: Africa Energy Unit (AFTEG), World Bank

Groves, D.G. and Lempert, R.J. (2007) A new analytic method for finding policy-relevant scenarios, Global Environmental Change 17 pp73-85

Groves, D.G. and Lempert, R.J. (2010) Identifying and evaluating robust adaptive policy responses to climate change for water management agencies in the American west, Technological Forecasting \& Social Change 77 pp 960-974

Hammond, M. (2013) The Grand Ethiopian Renaissance Dam and the Blue Nile: Implications for transboundary water governance, Global Water Forum Discussion paper 1307, February 2013 Available at: http://www.globalwaterforum.org/wp-content/uploads/2013/02/The-Grand-Ethiopian-Renaissance-Dam-andthe-Blue-Nile-Implications-for-transboundary-water-governance-GWF-1307.pdf [Accessed 26 August 2014]

Hamududu, B. and Killingtveit, A. (2012) Assessing climate change impacts on global hydropower, Energies 2012, 5, pp305-322; doi:10.3390/en5020305

Harrison, G.P. and Whittington, H.W. (2001) Impact of climatic change on hydropower investment. in Proceedings of the 4th International Conference on Hydropower Development (Hydropower'01) (pp. 19-22)

Harrison, G., Whittington, H. W. and Wallace, R. (2003) Climate change impacts on financial risk in hydropower projects. IEEE Transactions on Power Systems. 18, 4, p1324-1330

$\mathrm{He}, \mathrm{X}$. (2013) Integrating climate change factors within China's Environmental Impact Assessment legislation: New challenges and developments, 9/1 Law, Environment and Development Journal (2013), p. 50, [WWW] Available at http://www.lead-journal.org/content/13050.pdf (accessed 12 January 2015)

Hydropower and dams (2009) World hydropower atlas

limi, A. (2007) Estimating global climate change impacts on hydropower projects: Applications in India, Sri Lanka and Vietnam. World Bank Policy Research Working Paper No. 4344. Washington, DC

Infrastructure Consortium for Africa (ICA) (2011) Regional power status in African power pools report, November 2011

International Energy Agency (IEA) (2011) Energy for all: Financing access for the poor, October 2011 Intergovernmental Panel on Climate Change (IPCC). (2014) Fifth Assessment Report Climate change 2014: Impacts, adaptation and vulnerability, Geneva, [WWW] Available at: http://www.ipcc.ch/report/ar5/wg2/ [Accessed 6 January 2015] 
International Panel of Experts Grand Renaissance Dam (2013) International Panel of Experts on the Grand Renaissance Dam: Final report, Addis Ababa, Ethiopia 31 May 2013 [WWW] Available at: http://www.internationalrivers.org/files/attachedfiles/international panel of experts for ethiopian renaissance dam- final report 1.pdf [Accessed 22 August 2014]

International Renewable Energy Agency (IRENA) (2013) Southern African power pool: Planning and prospects for renewable energy [WWW] Available at: http://www.irena.org/DocumentDownloads/Publications/SAPP.pdf [Accessed 22 August 2014]

International Rivers (2012) The new great walls: A guide to China's overseas dam industry, Second Edition, November 2012 [WWW] http://www.internationalrivers.org/files/attachedfiles/intlrivers newgreatwalls 2012 0.pdf (Accessed 26 December 2014) International Rivers (2014) Bui Dam, Ghana [WWW] Available at: http://www.internationalrivers.org/resources/bui-dam-ghana-3608 [Accessed 17 September 2014] International Research Institute for Climate and Society (IRI) (2006) A global gap analysis for the implementation of the Global Climate Observing System Programme in Africa. Palisades, NY, USA: International Research Institute for Climate and Society [WWW] Available at: http://iri.columbia.edu/docs/publications/GapAnalysis.pdf (Accessed 23 December 2014 )

Jeuland, M. and Whittington, D. (2013) Water resources planning under climate change: A "real options" application to investment planning in the Blue Nile, Environment for Development, Discussion Paper Series, March 2013, [WWW] Available at: http://www.rff.org/rff/documents/EfD-DP-13-05.pdf (Accessed 26 December 2014)

Kim, U., Kaluarachchi, J. J. and Smakhtin, V.U. (2008) Climate change impacts on hydrology and water resources of the Upper Blue Nile River Basin, Ethiopia, International Water Management Institute (IWMI), IWMI Research Report 126, pp27

Kling, H. Stanzel, P. and Preishuber, M. (2014) Impact modelling of water resources development and climate scenarios on Zambezi River discharge, Journal of Hydrology: Regional Studies, Volume 1, p17-43 Available at: http://www.sciencedirect.com/science/article/pii/S2214581814000032 [Accessed 17 September 2014]

Kumar, A., Schei, T., Ahenkorah, A., Caceres Rodriguez, R., Devernay, J-M. Freitas, M., Hall, D., Killingtveit, Å. \& Liu, Z. (2011) 'Hydropower', in Edenhofer, O., Pichs-Madruga, R., Sokona, Y., Seyboth, K., Matschoss, P., Kadner, S., Zwickel, T., Eickemeier, P., Hansen, G., Schlömer, S. \& von Stechow, C. (eds.) (2011) IPCC Special Report on Renewable Energy Sources and Climate Change Mitigation. Cambridge University Press

Lumbroso, D.; Hurford, A.; Winpenny, J.; Wade, S. (2014) Harnessing hydropower: Literature review, Evidence on Demand, UK dx.doi.org/10.12774/eod_cr.august2014.lumbrosoetal1

Marks, D. (2010) China's climate change policy process: Improved but still weak and fragmented, Journal of Contemporary China, 19: 67, pp971 - 986

McCornick, P., Smakhtin, V., Bharati, L., Johnston, R., McCartney, M., Sugden, F., Clement, F. and Mclntyre, B. (2013) Tackling change: Future-proofing water, agriculture, and food security in an era of climate uncertainty. Colombo, Sri Lanka: International Water Management Institute (IWMI). 36p. doi: 10.5337/2013.21 
Milly, P., Betancourt, J., Falkenmark, M., Hirsch, R. and Zbigniew, W. (2008) Climate change - Stationarity is dead: whither water management?, Science 319, pp573-574.

Moss, T. and Gleave, M. (2014) Benefits and costs of the energy targets for the post-2015 development agenda

Mullan, F., Frehywot, S., Omaswa, F., Buch, E., Chen, C., Greysen, S. R. and Neusy, A. J. (2011). Medical schools in sub-Saharan Africa, The Lancet, 377(9771), pp1113-1121.

MWH (2009) Water and climate change: Assessment of climate change impacts on multi-purpose water infrastructure, World Bank August 2009

Němec, J., and Schaake, J. (1982). Sensitivity of water resource systems to climate variation. Hydrological Sciences Journal, 27(3), pp327-343.

Pittock, J. (2010) Viewpoint - Better management of hydropower in an era of climate change, Water Alternatives 3(2), pp444-452

Pottinger, L. (2009) Africa: The wrong climate for big dams, World Rivers Review

Pöyry (2011) China and renewable energy in Africa: Opportunities for Norway? Available at: http://www.iaea.org/inis/collection/NCLCollectionStore/ Public/43/103/43103515.pdf [Accessed 24December 2014]

Rydgren, R., Graham, P., Basson, M. and Wisaeus, D. (2007) Addressing climate-driven increased hydrological variability in environmental assessments for hydropower projects: A scoping study. World bank, Washington D.C. Available at: http://www-

wds.worldbank.org/external/default/WDSContentServer/WDSP/IB/2012/07/31/000333037 20120731015331 /Rendered/PDF/715290WP0Box370077B00PUBLIC00IHV0Final.pdf [Accessed 14 August 2014]

Sackitey, F. (2012) Powering up Ghana: A Ghana-China collaboration to fill the growing need for electricity, CHINAFRICA, Vol 4, January 2012. Available at: http://www.chinafrica.cn/english/africa report/txt/201112/31/content 418063.htm [Accessed 18 September 2014]

Schaeffer, R., Szklo, A.S., Pereira de Lucena, A.F., Soares, B., Borba, M.C., Nogueira, L.P.P., Fleming, F.P., Troccoli, A., Harrison, M., Boulahya, M.S. (2012) Energy sector vulnerability to climate change: A review, Energy 38:1-12. doi:10.1016/j.energy.2011.11.056

Spalding-Fecher, R., Chapman, A., Yamba, F., Walimwipi, H., Kling, H., Tembo, B., Nyambe, I., and Cuamba, B. (2014) The vulnerability of hydropower production in the Zambezi River Basin to the impacts of climate change and irrigation development, Mitigation and Adaptation Strategies for Global Change, DOI 10.1007/s11027-014-9619-7

Veilleux, J. (2013) The human security dimensions of dam development: The Grand Ethiopian Renaissance Dam, Global Dialogue Volume 15, Number 2, Summer/Autumn 2013, Water: Cooperation or Conflict?

Woodhouse ,P. and Ganho, A.S. (2011) Is water the hidden agenda of agricultural land acquisition in subSaharan Africa? Paper presented at the International Conference on global land grabbing, 6-8 April 2011

World Bank (2009) Powering up: Costing power infrastructure spending needs in sub-Saharan Africa, Summary, March 2009, World Bank, Washington DC

World Bank (2014) Electric power consumption (kWh per capita) for 2011 [WWW] http://data.worldbank.org/indicator/EG.USE.ELEC.KH.PC (Accessed 23 December 2014) 